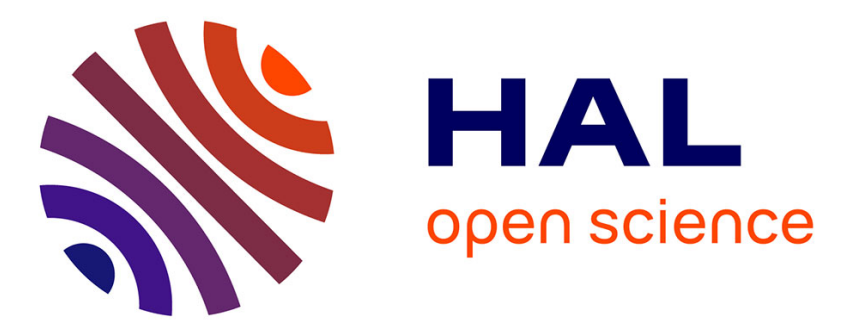

\title{
A recovery process of strontium from acidic nuclear waste streams
}

M. Draye, Gérard Le Buzit, Jacques Foos, Alain Guy, Bruno Leclere, Pierre Doutreluigne

\section{- To cite this version:}

M. Draye, Gérard Le Buzit, Jacques Foos, Alain Guy, Bruno Leclere, et al.. A recovery process of strontium from acidic nuclear waste streams. Separation Science and Technology, 1997, 32, pp.17251737. 10.1080/01496399708000731 . hal-00006557

\section{HAL Id: hal-00006557 \\ https://hal.science/hal-00006557}

Submitted on 1 Oct 2021

HAL is a multi-disciplinary open access archive for the deposit and dissemination of scientific research documents, whether they are published or not. The documents may come from teaching and research institutions in France or abroad, or from public or private research centers.
L'archive ouverte pluridisciplinaire HAL, est destinée au dépôt et à la diffusion de documents scientifiques de niveau recherche, publiés ou non, émanant des établissements d'enseignement et de recherche français ou étrangers, des laboratoires publics ou privés. 


\title{
A Recovery Process of Strontium from Acidic Nuclear Waste Streams
}

\author{
M. DRAYE, * G. LE BUZIT, J. FOOS, and A. GUY \\ LABORATOIRE DES SCIENCES NUCLÉAIRES DU CNAM \\ 2 RUE CONTÉ, 75003 PARIS, FRANCE
}

B. LECLERE and P. DOUTRELUINGNE

SERVICE LABORATOIRES COGEMA

ETABLISSEMENT DE LA HAGUE

BP 508, 50105 CHERBOURG CÉDEX, FRANCE

M. LEMAIRE*

INSTITUT DE RECHERCHE SUR LA CATALYSE (CNRS)

LABORATOIRE DE CATALYSE ET SYNTHÈSE ORGANIQUE

CPE, 43. BOULEVARD DU 11 NOVEMBRE 1918, 69622 VILLEURBANNE CÉDEX. FRANCE

\begin{abstract}
A process combining liquid-liquid extraction with ion exchange for strontium traces removal in the presence of an excess of sodium concentrations is described. In this continuous process, strontium is extracted from acidic $(0.9 \mathrm{M})$ solution using a substoichiometric amount of dicyclohexano-18-crown-6 $\left(0.1 \mathrm{M}\right.$ in $\left.\mathrm{CHCl}_{3}\right)$. Extracted strontium is readily stripped from an organic phase with water and concentrated onto an ion exchanger. This process allows a high strontium decontamination factor (250) with a very important extraction factor (5000).
\end{abstract}

\section{INTRODUCTION}

Large volumes of liquid wastes are generated during spent nuclear fuel reprocessing. Weakly radioactive, these effluents impose a complex treatment composed of several steps of coprecipitations with various chemical reagents $\left[\mathrm{Ba}\left(\mathrm{NO}_{3}\right)_{2}, \mathrm{Fe}\left(\mathrm{NO}_{3}\right)_{2}, \ldots\right]$ before releasing, and although satis-

* To whom correspondence should be addressed. 
factory at the level of the rejection norms presently enforced, the method presents many disadvantages. The method is not very selective; it generates important amounts of low activity solid wastes and requires a significant volume of chemical reagents before disposal can occur. Because of both the assumed high cost of waste immobilization and disposal, and the increasing concern toward protection of the environment (2), a more effective process to minimize the volume of waste is desirable. Among the radioactive elements present as traces in the liquid wastes (Table 1), ${ }^{90} \mathrm{Sr}$, which has chemical properties close to those of calcium, is known for its harmful biological effects on bone cells. Nevertheless ${ }^{90} \mathrm{Sr}$, because of the heat it generates, should be of value as a reliable source of thermal energy for use in radioisotopic thermal electric generators (3) and could have significant beneficial applications.

Recently, solvent extraction and ion-exchange processes for strontium isolation from alkaline and weak or strong acid waste solutions have been developed. The use of dicyclohexano-18-crown-6 (DCH18C6), a very stable crown ether $(4,5)$, and its dimethyl and di-t-butyl derivatives for the removal of $\mathrm{Sr}$ from acidic media is well documented in the literature (6-11). Many studies have focused on improvement of the efficiency of crown ethers by using different solvents and/or additives (12-15). Ionexchange processes employing inorganic ion exchangers such as antimonic acid for sorbing ${ }^{90} \mathrm{Sr}$ from strong $\left(0.5\right.$ to $\left.7 \mathrm{M} \mathrm{HNO}_{3}\right)$ acid waste solutions have been extensively studied (16). On the other hand, the use of organic ion exchangers containing functional groups for the separation of metal ions has been reported (17-19) only from basic solutions. Many processes have been described for the removal of strontium from acidic or basic solutions. Without exception, however, these processes involve strontium concentrations from 70 (20) to 500 (13) times higher than these of the effluents we describe.

TABLE 1

Composition of the Effluents Produced by All the Industrial Wholes of the Spent Nuclear Fuel Reprocessing Plant of COGEMA La Hague (before treatment)

\begin{tabular}{lccccccc}
\hline Element & $\mathrm{Na}$ & $\mathrm{Zn}$ & $\mathrm{Mg}$ & $\mathrm{Fe}$ & $\mathrm{Ca}$ & $\mathrm{K}$ & $\mathrm{Al}$ \\
\hline $\begin{array}{c}\text { Concentration } \\
\left(\mathrm{mg} \cdot \mathrm{L}^{-1}\right)\end{array}$ & 1870 & 80 & 50 & 7 & 5 & 6 & 3 \\
\hline Element & $\mathrm{Cr}$ & $\mathrm{Ru}$ & $\mathrm{Cs}$ & $\mathrm{Pu}$ & $\mathrm{Sr}$ & $\mathrm{Sb}$ & $\mathrm{Pb}$ \\
\hline $\begin{array}{c}\text { Concentration } \\
\left(\mathrm{mg} \cdot \mathrm{L}^{-1}\right)\end{array}$ & 0.60 & 0.50 & 0.35 & 0.13 & $6 \times 10^{-3}$ & $2 \times 10^{-4}$ & $<0.10$ \\
\hline
\end{tabular}


The aim of this paper is to report a new continuous process combining liquid-liquid extraction with ion exchange for strontium trace removal in the presence of an excess of sodium. The association of these two techniques allows a high strontium decontamination factor and a very important extraction factor (1).

The coextraction of metals present in liquid waste by solvent extraction which utilizes DCH18C6 as the Sr extractant has been studied. As reported by Horwitz et al. (21), the distributions ratios measured with 0.2 $\mathrm{M}$ DtBuDCH18C6 in 1-octanol were lower than 1 for all elements except strontium.

\section{EXPERIMENTAL}

\section{Strontium Extraction Procedure}

Chemicals and Reagents. All reagents were purchased commercially and used as received. The mixture of DCH18C6 isomers was supplied by Fluka, and the DCH18C6 isomers were separated according to a procedure previously reported (22). DUOLITE ARC 9652 resin (18-40 mesh, sulfonate form) was purchased from Rohm \& Haas Industries. One gram of resin contains 1.2 meq of strong acid exchange sites $\left(\mathrm{SO}_{3} \mathrm{H}\right)$. The simulated aqueous wastes were prepared by dissolving salts of sodium and strontium nitrates in nitric acid. The composition of the synthetic waste used in this study is shown in Table 2.

Liquid-Liquid Procedure. Equal volumes $(3 \mathrm{~mL}$ ) of simulated aqueous waste and organic DCH18C6 in the chosen solvent were shaken for 15 minutes in sealed tubes. The two phases were separated by centrifugation, and the strontium was then stripped from the organic phase by backextraction to an aqueous receiving phase ( $3 \mathrm{~mL}$ of distilled water).

\section{Ion-Exchange Study}

Batch Procedure. The kinetics of Sr extraction were studied by shaking $1 \mathrm{~mL}$ of resin with $5 \mathrm{~mL}$ of a $0.9 \mathrm{M}$ nitric acid solution containing $0.545 \times 10^{-3} \mathrm{~g} \cdot \mathrm{L}^{-1}$ of $\mathrm{Sr}$ and $4.18 \mathrm{~g} \cdot \mathrm{L}^{-1}$ of $\mathrm{Na}$. After 1 to 18 hours of

TABLE 2

Chemical Composition of the Synthetic Effluents

\begin{tabular}{lcccc}
\hline Ion & $\mathrm{H}^{+}$ & $\mathrm{NO}_{3}^{-}$ & $\mathrm{Na}^{+}$ & $\mathrm{Sr}^{2+}$ \\
\hline Concentration $\left(\mathrm{mol} \cdot \mathrm{L}^{-1}\right)$ & 0.9 & 1 & 0.1 & $2.68 \times 10^{-6}$ \\
\hline
\end{tabular}


shaking, the solution was filtered and the concentration of $\mathrm{Sr}$ in the aqueous phase was measured to determine the distribution coefficient $D$.

Column Procedure. The desired volume of resin, $6 \mathrm{~mL}$, was collected in a glass tube $(h / \phi=12)$. Sr fixation was performed by passing the effluent through the column at a flow rate of $0.17 \mathrm{~L} \cdot \mathrm{h}^{-1}$. Strontium was then eluted with $5 \mathrm{M} \mathrm{HNO}_{3}$.

\section{Distribution Ratios}

Liquid-Liquid Study. Distribution ratios of $\mathrm{Sr}$ and $\mathrm{Na}$ were determined radiometrically. The isotopes used were ${ }^{85} \mathrm{Sr}(65 \mathrm{~d})$ and ${ }^{22} \mathrm{Na}(2.6$ y). $514 \mathrm{keV} \gamma$-energy was used for ${ }^{85} \mathrm{Sr}$ determination, $511 \mathrm{keV} \gamma$-energy was used for ${ }^{22} \mathrm{Na}$ determination in the absence of ${ }^{85} \mathrm{Sr}$, and $1274 \mathrm{keV}$ ${ }^{22} \mathrm{Na} \gamma$-energy was used for ${ }^{22} \mathrm{Na}$ determination in the presence of ${ }^{85} \mathrm{Sr}$.

lon-Exchange Study. Distribution ratios of $\mathrm{Sr}$ were measured both radiometrically using the $514 \mathrm{keV} \gamma$-energy of ${ }^{85} \mathrm{Sr}(65 \mathrm{~d})$ and by atomic absorption spectrometry. Distribution ratios of $\mathrm{Na}$ were measured by atomic absorption spectrometry.

\section{Analytical Section}

Measurements of the Activity by $\gamma$-Ray Spectrometry. The INTERTECHNIQUE IN 1200 equipment was composed of a high-purity semiconductor Ge detector type, a preamplifier, an amplifier, a coder, an analyzer, and computer treatment. The concentrations of $\mathrm{Sr}$ and $\mathrm{Na}$ were measured with a standard deviation of $\pm 5 \%$.

Atomic Absorption Spectrometry Measurements. The concentrations of $\mathrm{Na}$ and $\mathrm{Sr}$ were determined by atomic absorption spectrometry using a Perkin-Elmer 5100 spectrometer (air-acetylene flame). In the case of $\mathrm{Sr}$ for which the amounts for analysis were extremely small, we had to use electrothermal atomization (furnace-AAS). Analyses were typically reproductible to within $\pm 5 \%$.

\section{RESULTS AND DISCUSSION}

\section{Liquid-Liquid Extraction of Strontium}

The nature of the solvent, the stereochemical configuration of the DCH18C6 isomer, and the extractant concentration were used to study the removal of strontium traces in the presence of excess sodium.

The distribution ratio of each metal in the liquid-liquid distribution, representing the ratio of the total analytical concentration of a metal in the extract (regardless of its chemical form) to its total analytical concentration in the other phase, was expressed as 


$$
D=[\overline{\mathrm{M}}] /[\mathrm{M}]
$$

and calculated from the experimental data, where $[\bar{M}]$ and $[\mathrm{M}]$ were the total metal concentrations in the organic and aqueous phases, respectively.

The separation factor, representing the ratio of the respective distribution ratios of the two extractible metals measured under the same conditions, was calculated as follows:

$$
\alpha_{\mathbf{M}_{1}, \mathbf{M}_{2}}=D_{\mathbf{M}_{1}} / D_{\mathbf{M}_{2}}
$$

\section{Extraction Step}

Choice of the Solvent. The nature of the solvent used can affect the extraction selectivity (23-25). The selection of an appropriate solvent requires that certain factors be taken into consideration: the solvent must have an acceptable density, its water solubility must be low, and its phase disengagement from mixtures with nitric acid must be rapid. The partition of DCH18C6 between water and various solvents was measured in the presence of potassium picrate by the Frensdorff's method (26), and the percentage of DCH18C6 loss was expressed by

$$
p \%=\frac{[\mathrm{L}]}{[\overline{\mathrm{L}}]} \times 100
$$

where $[\mathrm{L}]$ and $[\overline{\mathrm{L}}]$ indicate the concentrations of DCH18C 6 in the aqueous and organic phases, respectively.

Among all the solvents tested, only those resulting in a macrocycle loss below $7 \%$ were selected. The influence of 26 solvents on $\mathrm{Sr}$ selectivity of extraction was studied in an attempt to correlate strontium extraction with the physicochemical properties of the solvents (dipole moment $\mu$, dielectric constant $\epsilon$, and Hildebrand parameter $\delta$ ). Table 3 summarized the distribution ratios obtained as a function of the solvent used and of its physicochemical properties. Four classes of solvent were selected for the study: chlorinated hydrocarbons, alcohols, carboxylic acids, and aromatics.

It is interesting to note that chlorinated solvents give the highest $\mathrm{Sr}$ distribution ratios and the best separation factors. DCH 18C6 is less effective for $\mathrm{Sr}$ extraction when diluted in primary or secondary alcohols, but there appears to be no correlation between the number of carbons of the aliphatic chain, the class of the alcohol, and the Sr efficiency of extraction. The same conclusions can be drawn regarding the $D$ and $\alpha$ values obtained when DCH18C6 is diluted in carboxylic acids. 
TABLE 3

Comparison of Strontium Distribution Ratios in Various Solvents, $T=25^{\circ} \mathrm{C}$, DCH18C6 $=0.1 \mathrm{~mol} \cdot \mathrm{L}^{-1}$, Initial $\mathrm{HNO}_{3}=0.9 \mathrm{~mol} \cdot \mathrm{L}^{-1}$

\begin{tabular}{|c|c|c|c|c|c|c|c|}
\hline Solvent & $p \%$ & $D S r$ & $\mathrm{DNa}$ & $\alpha_{\mathrm{Sr}, \mathrm{Na}}$ & $\epsilon_{r}^{a}$ & $\mu^{b}$ & $\delta^{c}$ \\
\hline Chloroform & 0.05 & 25.00 & $\leq 0.01$ & $\geq 2500$ & 4.81 & 3.84 & 9.16 \\
\hline Dichloromethane & 0.08 & 26.00 & 0.02 & 1300 & 9.08 & 5.17 & 9.88 \\
\hline 1,2-Dichloroethane & 0.35 & 14.00 & 0.03 & 467 & 10.65 & 6.20 & 9.86 \\
\hline 1,1,1-Trichloroethane & 1.80 & 0.17 & $\leq 0.01$ & 17 & 7.53 & 5.20 & 8.30 \\
\hline 1-Chloropentane & 6.20 & 0.02 & $\leq 0.01$ & $\geq 2$ & 6.60 & 1.94 & 8.33 \\
\hline 1-Pentanol & 1.05 & 2.25 & 0.11 & 20 & 13.90 & 5.94 & 10.90 \\
\hline 1-Heptanol & 1.50 & 0.87 & 0.07 & 12 & 11.55 & 3.07 & 10.50 \\
\hline 1-Octanol & 2.00 & 0.6 & 0.05 & 12 & 10.34 & 5.81 & 10.30 \\
\hline 1-Decanol & 2.90 & 0.35 & 0.04 & 9 & 8.10 & - & 8.60 \\
\hline 2-Octanol & 3.50 & 0.34 & 0.03 & 11 & 8.17 & 5.54 & 7.90 \\
\hline 2-Ethylhexanol & 2.00 & 0.47 & 0.02 & 24 & 4.41 & - & 9.85 \\
\hline Cyclohexanol & 1.65 & 2.30 & 0.15 & 15 & 15.00 & 6.20 & 11.40 \\
\hline Pentanoic acid & 0.16 & 2.53 & 0.11 & 23 & 2.66 & 1.12 & 8.50 \\
\hline Hexanoic acid & 0.22 & 1.08 & 0.03 & 36 & 2.63 & 1.13 & 8.51 \\
\hline Heptanoic acid & 0.29 & 0.64 & 0.02 & 32 & 2.60 & 1.14 & 8.53 \\
\hline Octanoic acid & 0.40 & 0.37 & $\leq 0.01$ & $\geq 37$ & 2.45 & 1.15 & 8.56 \\
\hline 2-Ethylhexanoic acid & 0.55 & 0.18 & $\leq 0.01$ & $\geq 18$ & 2.40 & 1.13 & 8.10 \\
\hline Benzene & 1.30 & 0.21 & $\leq 0.01$ & $\geq 21$ & 2.28 & 0.00 & 9.16 \\
\hline Chlorobenzene & 0.84 & 1.25 & $\leq 0.01$ & $\geq 125$ & 5.71 & 5.14 & 9.67 \\
\hline Bromobenzene & 0.88 & 1.24 & $\leq 0.01$ & $\geq 124$ & 5.40 & 5.17 & 9.87 \\
\hline Iodobenzene & 1.30 & 0.93 & $\leq 0.01$ & $\geq 93$ & 4.63 & 4.64 & 10.13 \\
\hline Toluene & 0.05 & 0.05 & $\leq 0.01$ & $\geq 5$ & 8.93 & 1.43 & 8.93 \\
\hline Nitrobenzene & 0.70 & 6.00 & 0.05 & 120 & - & 13.44 & 10.40 \\
\hline Benzonitrile & 0.70 & 11.00 & 0.12 & 92 & 2.33 & 13.51 & 10.70 \\
\hline 1,2-Dichlorobenzene & 0.90 & 1.05 & $\leq 0.01$ & $\geq 105$ & 35.74 & 7.57 & 10.04 \\
\hline 1,2,4-Trichlorobenzene & 2.30 & 0.36 & $\leq 0.01$ & $\geq 36$ & 24.20 & 13.50 & 12.38 \\
\hline
\end{tabular}

${ }^{a}$ Electric dipole moment.

${ }^{b}$ Dipole moment.

' Hildebrand function $(27,28)$.

Aromatics are more effective solvents than alcohols and carboxylic acids, which are in turn less effective diluents than alcohols.

The solvent effect on both $\mathrm{Sr}$ efficiency and selectivity of extraction is not well understood and cannot be rationalized on the basis of its polarity ( $\mu$ and $\epsilon$ ) or its H-bonding ability ( $\delta$ ). In general, however, the best results are obtained with chlorinated solvents and especially with chloroform for which the required strontium distribution ratios and selectivity are observed. In order to test the potential value of our methodology, chloro- 
TABLE 4

Distribution Ratios and Separation Factors as a Function of the DCH18C6 Stereochemical Configuration, $T=25^{\circ} \mathrm{C}, 0.1 \mathrm{M} \mathrm{DCH} 18 \mathrm{C} 6$

\begin{tabular}{lccc}
\hline \multirow{2}{*}{$\begin{array}{l}\text { DCH18C6 } \\
\text { isomer }\end{array}$} & \multicolumn{2}{c}{ Distribution ratio, $D$} & $\begin{array}{c}\text { Separation Factor, } \\
\alpha_{\text {Sr.Na }}=D S r / D N a\end{array}$ \\
\cline { 2 - 3 } & $D \mathrm{Sr}$ & $D \mathrm{Na}$ & 2000 \\
cis-syn-cis & 30 & 0.015 & 1875 \\
cis-anti-cis & 15 & 0.008 & 2000 \\
Mixture & 26 & 0.013 & \\
\hline
\end{tabular}

form was chosen as our test solvent, despite its tendency to generate corrosive $\mathrm{HCl}$ upon radiolysis.

Dependence of Strontium/Sodium Separation on the Stereochemical Configuration of the DCH18C6 Isomers. The distribution ratio variation as a function of the stereochemical configuration of the DCH18C6 isomers used are listed in Table 4.

A high distribution ratio and separation factor for strontium are observed with the cis-syn-cis isomer, and this conclusion is consistent with results previously reported by Yakshin et al. (29). Strontium and sodium distribution ratios are lowest with a mixture of the two isomers, but they lead to the same separation factor as for the cis-syn-cis isomer.

Dependence of Strontium/Sodium Separation on DCH18C6 Concentration. The distribution ratio variations as a function of the DCH18C6 concentration are summarized in Table 5.

Good strontium distribution ratios are observed from a DCH18C6 concentration of $0.06 \mathrm{~mol} \cdot \mathrm{L}^{-1}$. The distribution ratio of strontium as well as

TABLE 5

Influence of the DCH18C6 Concentration on the Distribution Ratios and Separation Factors, $T=25^{\circ} \mathrm{C}$

\begin{tabular}{cccc}
\hline \multirow{2}{*}{$\begin{array}{c}\text { DCH18C6 } \\
\left(\mathrm{mol} \cdot \mathrm{L}^{-1}\right)\end{array}$} & \multicolumn{2}{c}{ Distribution ratio, $D$} & \multicolumn{2}{c}{$\begin{array}{c}\text { Separation factor, } \\
\alpha_{\mathrm{Sr}, \mathrm{Na}}=D S \mathrm{~S} / D \mathrm{Na}\end{array}$} \\
\cline { 2 - 4 } $\mathrm{DSr}$ & $D \mathrm{Na}$ & 1472 \\
0.01 & 2.65 & 0.0018 & 1513 \\
0.02 & 5.45 & 0.0036 & 1816 \\
0.04 & 10.9 & 0.0060 & 1987 \\
0.06 & 15.5 & 0.0078 & 2042 \\
0.10 & 24.5 & 0.0120 & \\
\hline
\end{tabular}


the selectivity of strontium over sodium are excellent for a DCH18C6 concentration of $0.1 \mathrm{~mol} \cdot \mathrm{L}^{-1}$.

\section{Stripping Step}

We have studied the dependence of sodium and strontium stripping on the concentration of the nitric acid solution. Indeed, it was necessary to define a range of nitric acid concentration where the extent of both strontium and sodium stripping is maximum. Stripping of sodium and strontium as a function of nitric acid concentration is represented in Fig. 1.

Strontium extraction leads to the formation of a complex with a strontium/ligand/nitrate stoichiometry of $1 / 1 / 2$ :

$$
\begin{gathered}
\overline{\mathrm{L}}+\mathrm{Sr}^{2+}+2 \mathrm{NO}_{3}^{-} \rightleftharpoons \overline{\mathrm{LSr}\left(\mathrm{NO}_{3}\right)_{2}} \\
K_{\mathrm{ex}}=\frac{\left[\overline{\mathrm{LSr}\left(\mathrm{NO}_{3}\right)_{2}}\right.}{[\overline{\mathrm{L}}]\left[\mathrm{Sr}^{2+}\right]\left[\mathrm{NO}_{3}^{--}\right]^{2}}
\end{gathered}
$$

The expression of the extraction constant (30) shows that a decrease of the nitrate concentration is responsible for decomplexation of the metals.

Water leads to the release of the major part of strontium as well as of sodium from the organic phase whereas an increase in nitric acid concentration is responsible for an increase in nitrate ions and decreases in both strontium and sodium stripping. The deciding factor for strontium stripping is the nitrate concentration.

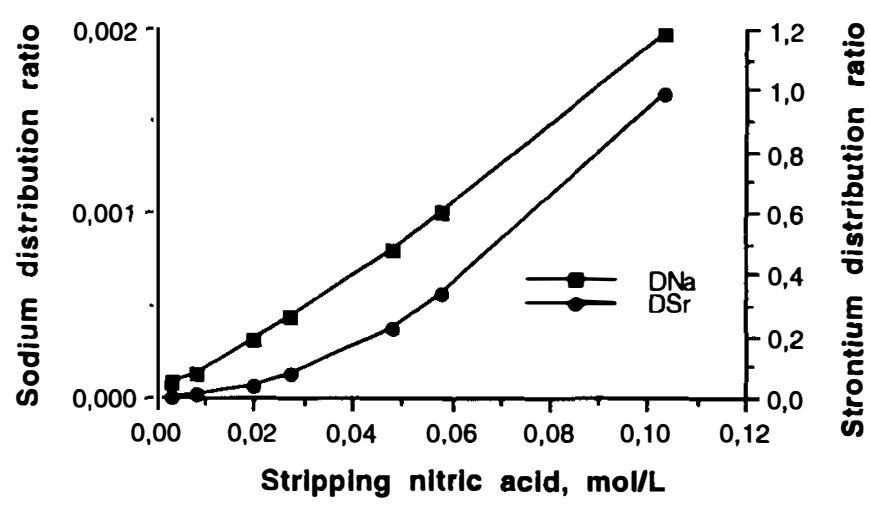

FIG. 1 Dependence of sodium and strontium stripping on nitric acid concentration. $\mathrm{DCH} 8 \mathrm{C6}=0.1 \mathrm{~mol} \cdot \mathrm{L}^{-1} . T=25^{\circ} \mathrm{C}$. 


\section{Solid-Liquid Concentration of Strontium}

Duolite ARC-9652 is a sulfonic acid cation-exchange macroporous resin.

\section{Batch Concentration of Strontium}

The distribution coefficients $D$ were calculated as follows:

$$
D=\frac{C_{\mathrm{i}}-C_{\mathrm{f}}}{C_{\mathrm{f}}} \times \frac{V}{m}
$$

where $C_{\mathrm{i}}$ and $C_{\mathrm{f}}=$ concentrations of strontium before and after concentration onto the resin

$$
\begin{aligned}
V & =\text { volume of solution }(\mathrm{mL}) \\
m & =\text { mass of resin }(\mathrm{g})
\end{aligned}
$$

Sorption kinetics of $\mathrm{Sr}$ concentration on the DUOLITE ARC-9652 from $0.9 \mathrm{~mol} \cdot \mathrm{L}^{-1}$ nitric acid containing sodium nitrate have been studied, and the results are shown in Fig. 2.

The extent of strontium concentration increases rapidly and appreciably up to 2 hours of shaking, at which time a plateau is reached. Maximum distribution ratios of $147 \mathrm{~mL} / \mathrm{g}_{(\mathrm{dry})}$ and of $5 \mathrm{~mL} / \mathrm{g}_{(\mathrm{dry})}$ are obtained after 18 hours of shaking for the strontium and the sodium, respectively.

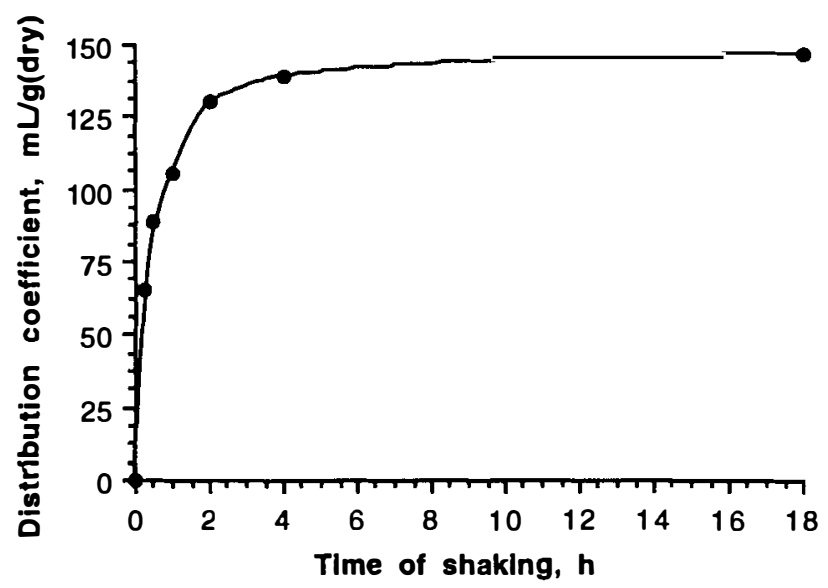

FIG. 2 Kinetic of concentration of traces of strontium onto the DUOLITE ARC-9652 in the presence of $4.18 \mathrm{~g} \cdot \mathrm{L}^{-1}$ of sodium. $\mathrm{HNO}_{3}=0.9 \mathrm{~mol} \cdot \mathrm{L}^{-1}$. 
In light of these results, removal of traces of strontium from $0.9 \mathrm{M}$ nitric solution containing an excess of sodium can be achieved using the DUOLITE ARC-9652 resin.

\section{Evaluation of a Continuous Process of Extraction-Stripping-Concentration of Strontium}

The number of theoretical stages of extraction was calculated using the "Kremser formula" (31a,b). In Fig. 3 a strontium stripping facility is proposed as a function of the concentrations for the nuclear waste streams studied.

The pilot installation requires a 3-stage extraction reactor and a 3-stage stripping reactor. The strontium is continuously concentrated onto an ionexchange resin. Extraction of more than $99 \%$ of the strontium in three stages needs a DCH18C6 concentration of $0.022 \mathrm{M}$.

A pH-adjusted synthetic effluent ( $\mathrm{pH} 0.46$ ) with a flow rate of $0.17 \mathrm{~L} \cdot \mathrm{h}^{-1}$ was added at the first stage and the extraction solvent was introduced at

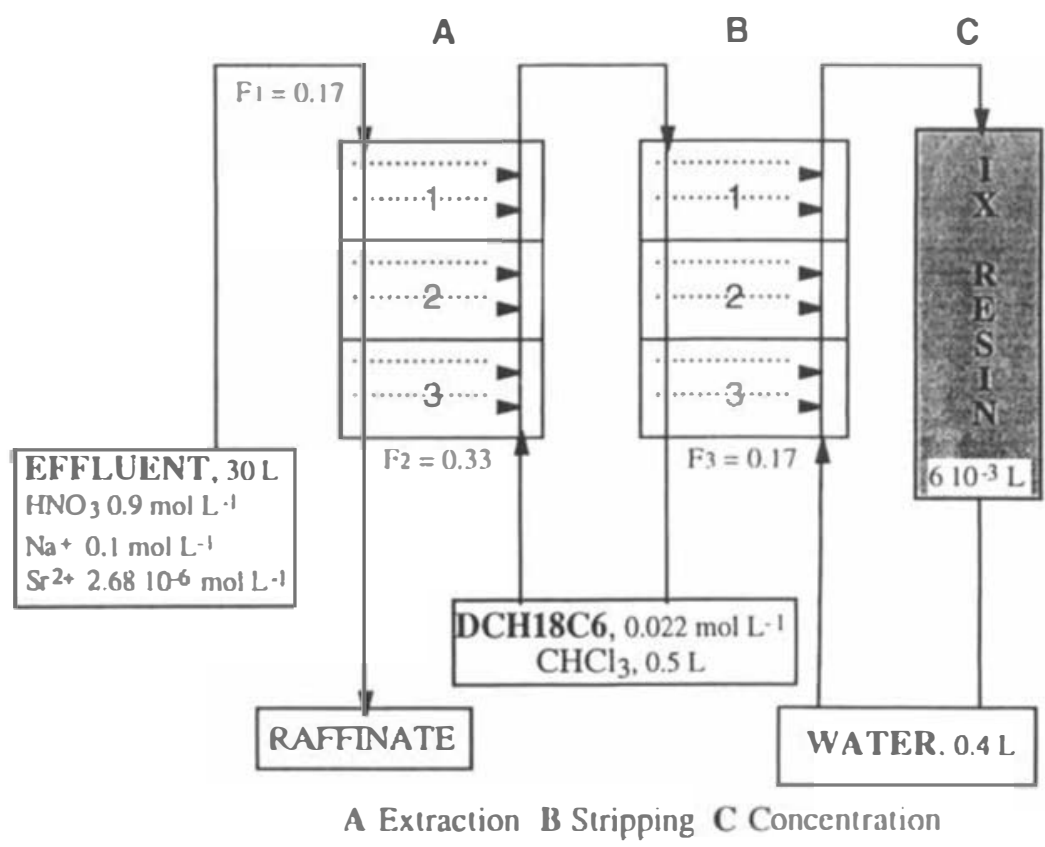

FIG. 3 Pilot installation for strontium extraction and recovery. $F_{1}=$ Effluent flow rate $\left(\mathrm{L} \cdot \mathrm{h}^{-1}\right) \cdot F_{2}=$ Organic phase flow rate $\left(\mathrm{L} \cdot \mathrm{h}^{-1}\right), F_{3}=$ Sr stripping flow rate $\left(\mathrm{L} \cdot \mathrm{h}{ }^{-1}\right)$. 
the third stage with a flow rate of $0.33 \mathrm{~L} \cdot \mathrm{h}^{-1}$. The majority of strontium (99.6\%) was extracted in three stages. The strontium was stripped in three stages, water was introduced at the third stage at a flow rate of $0.17 \mathrm{~L} \cdot \mathrm{h}^{-1}$. More than $90 \%$ of the strontium was stripped and continuously concentrated on to an ion-exchange resin. Traces of strontium contained in 30 $\mathrm{L}$ of effluent were concentrated on to $6 \times 10^{-3} \mathrm{~L}$ of resin, leading to a calculated extraction factor of 5000; strontium was then readily eluted with $5 \mathrm{M} \mathrm{HNO}_{3}$. Sr decontamination factors ( $\mathrm{Sr}$ concentration in effluent/ $\mathrm{Sr}$ concentration in raffinate) of about 250 were measured.

Leak of Strontium in the Raffinate. An effluent flow rate of 0.17 $1 \cdot \mathrm{h}^{-1}$ and an organic phase flow rate of $0.33 \mathrm{~L} \cdot \mathrm{h}^{-1}$ led to a strontium leak in the raffinate of less than $0.5 \%$. An increase of the flow rate to 0.75 $\mathrm{L} \cdot \mathrm{h}^{-1}$ allowed $30 \mathrm{~L}$ of the effluent to be reprocessed in 40 hours of running time. At this flow rate an important strontium leak was observed in the raffinate. Figure 4 shows the concentration of strontium in the raffinate as a function of time.

One hour of running time allows a strontium leak in the raffinate of $3.7 \%$; up to 40 hours of running time the strontium concentration in the raffinate increases by about $0.03 \% \cdot \mathrm{h}^{-1}$. It is interesting to note that after 40 hours of running time with a flow rate of $0.75 \mathrm{~L} \cdot \mathrm{h}^{-1}$, the strontium leak in the raffinate does not exceed 5\%. Moreover, this leak can be avoided in using countercurrent reactors made of one or two additional stages.

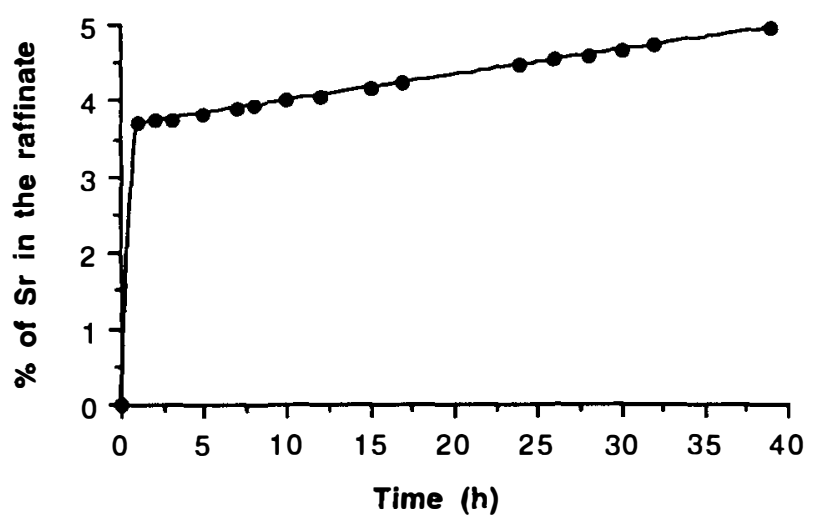

FIG. 4 Percentage of strontium in the raffinate as a function of the time. Effluent flow rate $=0.75 \mathrm{~L} \cdot \mathrm{h}^{-1}$. 


\section{CONCLUSION}

The results presented here demonstrate that a continuous process based on liquid-liquid extraction (DCH18C6 in chloroform)/solid-liquid concentration (ion exchanger) provides an effective method for the extraction and recovery of strontium traces in the presence of an excess of sodium from nitric acid media.

The liquid-liquid extraction study shows that the solvent effect on both Sr efficiency and selectivity of extraction is not well understood and cannot be rationalized on the basis of physicochemical parameters like $\mu, \epsilon$, or $\delta$. The best results are obtained with chlorinated solvents, especially with chloroform.

This process has several advantages over other previously described strontium extraction methods. The process uses commercially available reagents and works easily. Strontium contained in a 30-L sample of radioactive effluent is selectively extracted by the DCH18C6 and then concentrated onto $6 \mathrm{~mL}$ of an ion-exchange resin. The overall process therefore reduces the volume of material containing $\mathrm{Sr}$ by a factor of 5000 and fixes this soluble specie onto an organic incinerable material.

Although we have described only one specific application in this report, the process should be suitable for use with any environmental, biological, geological, or nuclear waste sample whose preparation requires digestion or leaching with nitric acid.

\section{ACKNOWLEDGMENT}

The authors are grateful to Dr. Graham Feast for helpful discussions.

\section{REFERENCES}

1. N. M. Rice, H. M. N. Irving, and M. A. Leonard, Pure Appl. Chem., 65(11), 2373 (1993)

2. G. Grossi and L. Cecille, in New'Separation Chemistry Techniques for Radioactive Waste and Other Specific Applications (L. Cecille, M. Casarci, and L. Pietrelli, Eds.), Elsevier Applied Science, London, 1991, p. 11.

3. W. W. Schulz and L. A. Bray, Sep. Sci. Technol., 22, 191 (1987).

4. M. Draye, R. Chomel, P. Doutreluingne, A. Guy, J. Foos, and M. Lemaire. J. Radioanal. Nucl. Chem., Lett., 175(1), 55 (1993).

5. M. Draye, A. Favre-Réguillon, R. Chomel, R. Faure, A. Guy, J. Foos, and M. Lemaire. Bull. Soc. Chim. Fr., 133(2), 183 (1996).

6. E. P. Horwitz, M. L. Dietz, and D. E. Fisher, Solv. Extr. Ion Exch., 8, 199 (1990).

7. E. P. Horwitz, M. L. Dietz, and D. E. Fisher, Ibid., 8, 557 (1990).

8. J. F. Dozol, J. Casas i Garcia, and A. M. Sastre, in New Separation Chemistry Tech- 
niques for Radioactive Waste and other Specific Applications (L. Cecille, M. Casarci, and L. Pietrelli, Eds.), Elsevier Applied Science, London, 1991, p. 173.

9. J. F. Dozol, J. Casas, and A. Sastre, J. Membr. Sci., 82, 237 (1993).

10. J. F. Dozol, J. Casas, and A. Sastre, Sep. Sci. Technol., 28(11\&12), 2007 (1993).

11. J. F. Dozol, J. Casas, and A. Sastre, Ibid., 29(15), 1999 (1994).

12. W. J. McDowell, Sep. Sci. Technol., 23, 1251 (1988).

13. E. P. Horwitz, M. L. Dietz, and D. E. Fisher, Solv. Extr. Ion Exch., 9(1), 1 (1991).

14. G. J. Lumetta, M. J. Wagner. and E. O. Jones, Sep. Sci. Technol., 30, 1087 (1995).

15. M. L. Dietz, E. P. Horwitz, and R. D. Rogers, Solv. Extr. Ion Exch ., 13(1), 1 (1995).

16. L. H. Baetsle, D. Van Deyck, and D. Huys, J. Inorg. Nucl. Chem., 27, 683 (1965).

17. M. A. Ebra, R. M. Wallace, D. D. Walker, and R. A. Wille, Sci. Basis Nucl. Waste Manage., 6, 633 (1982).

18. S. K. Samanta and M. Ramaswamy, Radiochim. Acta, 57, 201 (1992).

19. N. Dumont, A. Favre-Réguillon, B. Dunjic, and M. Lemaire, Sep. Sci. Technol., 3l(7), 1001 (1996).

20. D. J. Wood, T. J. Tranter, and T. A. Todd, Solv. Extr. Ion Exch., 13(5), 829 (1995).

21. E. P. Horwitz, M. L. Dietz, and D. E. Fisher, Ibid., 9(1), 1 (1991).

22. V. Guyon, P. Drognat Landré, A. Guy, J. Foos, and M. Lemaire, Chem. Lett., p. 723 (1992).

23. E. Blasius, W. Klein, and U. Schön, J. Radioanal. Nucl. Chem., Articles, 89(2), 389 (1985).

24. M. L. Dietz, E. P. Horwitz, and D. E. Fisher, Solv. Extr. Ion Exch., 8, 199 (1990).

25. M. L. Dietz, E. P. Horwitz, and D. E. Fisher, Ibid., 8(4\&5), 557 (1990).

26. H. K. Frensdorff, J. Am. Chem. Soc., 93(19), 4684 (1971).

27. M. Chastrette, M. Rajzmann, M. Chanon, and K. F. Purcell, Ibid., 107(1), 1 (1985).

28. C. Reichardt, in Solvents and Solvent Effects in Organic Chemistry, VCH Weinheim, New York, NY, 1988, pp. 408 410.

29. V. V. Yakshin, B. F. Myasoedov, O. M. Vilkova, A. M. Tuzova, A. T. Fedorova, and I. M. Radionova, Radiokhimiya, 31, 67 (1989).

30. Y. Takeda, Top. Curr. Chem. 121, I (1984)

31. (a) A. Kremser, Natl. Pet. News, 22(21), 42 (1930). (b) R. Treybal, in Chemical Engineers' Handbook (R. H. Perry and C. H. Chilton, Eds.), McGraw-Hill, New York, NY, 1973, Chap. 15-19. 